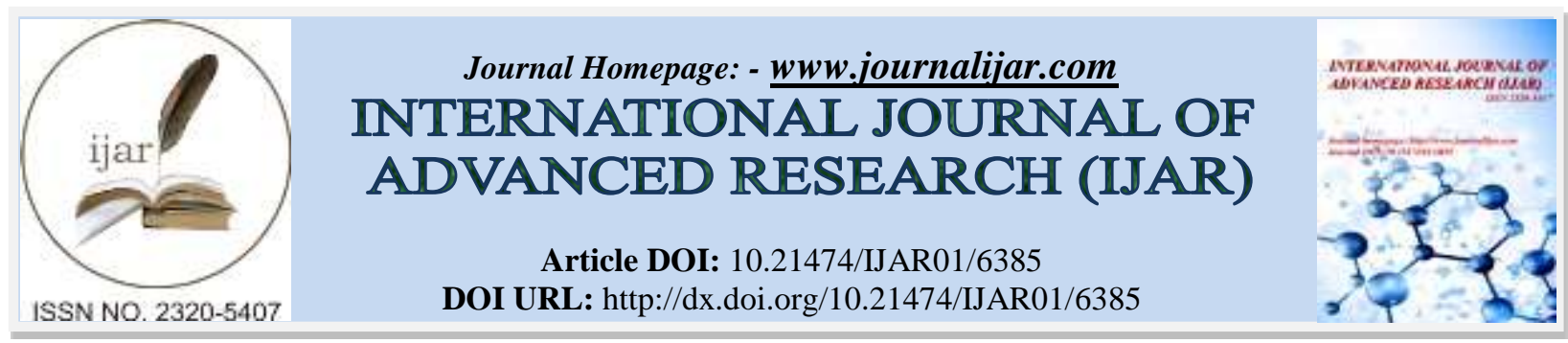

RESEARCH ARTICLE

\title{
EFFECTIVENESS OF GSECE LEARNING MODEL (GUIDING, SEARCHING, EXPERIENCING, COMMUNICATING, EVALUATING) FOR PHYSICS LEARNING AT VOCATIONAL HIGH SCHOOL.
}

Andik Kurniawan $^{1}$, Indrawati ${ }^{1}$, Sudarti ${ }^{1}$, Sutarto ${ }^{1}$, I Ketut Mahardika $^{1}$, and Iis Nur Asyiah ${ }^{1}$. Department of Post Graduate Science Education, Jember University, East Java, Indonesia.

\section{Manuscript Info}

\section{Manuscript History}

Received: 22 November 2017

Final Accepted: 24 December 2017

Published: January 2018

Key words:-

GSECE learning model, learning effectiveness.

\begin{abstract}
Abstract: This study aims to examine the effectiveness of GSECE learning model (Guiding, Searching, Experiencing, Communicating, Evaluating) for physics learning in Vocational High School. Effectiveness is determined by its impact on learning outcomes, student responses and student learning activities. This research was conducted at SMK Negeri 7 Jember with sample number 35 student of class $X$ TKJ. Methodology: This research type is quasi experiment with control group design pretest and post test in the experimental group (n = 35), Data collection techniques used tests, questionnaires and observations. Data analysis techniques use independent sample $t$ test to determine the impact of GSECE model on learning outcomes. Percentage technique to determine student response and student learning activities. Result: ressult of research that $t$ count $=4.75$ and $t$ table $=1,99$ ( $\mathrm{t}$ count $>\mathrm{t}$ table) and $\mathrm{P}$ value $(0,000<0,05)$ mean there is difference between experiment group and control group, percentage of student response in experiment group learning with GSECE learning model 78,46\% (good category), control group 60,45\% (good ), and percentage of learning activity of experimental group studying with GSECE 69,86\% (active category), control group 62.92\% (active category). Conclusion: the GSECE learning model is effective for physics learning as indicated by significant differences on learning outcomes, good student responses, and active learning category students' learning.
\end{abstract}

Copy Right, IJAR, 2018,. All rights reserved.

\section{Introduction:-}

Physics is part of the Natural Science (IPA) the essence of learning requires a process to find physics products in the form of concepts, theories, principles and laws through scientific measures. Therefore, the learning pattern that should be applied put forward the process skill approach rather than the outcome [1].

The fact that is often encountered in the field, teachers in doing physics learning more emphasis on aspects of mastery of the concept. Learning model used was more likely to conventional way that is with lectures and exercise questions, thus causing learners to be bored, less interested and less active in learning, and less awakening attitude of cooperation among learners. 
As a solution to the above problems, a workable solution is to improve the learning process. There is also one of the learning models that can be proposed is the GSECE learning model. This learning model takes shelter under constructivism learning which emphasizes that knowledge built into the mind of learners and this learning model emphasizes the meaningfulness of learning. Constructivist learning is based on the fact that skills and knowledge gained are not passively accepted and memorized but involve the active participation of learners through thought and immediate activity so that knowledge will be developed [2]. A truly contextual learning will occur when students (learners) are able to process new information or knowledge in such a way as the student's mind of reference (memory, experience, and response) [3]. In addition learning in contextual learning tends to look for meaning, search for sensible relationships, as well as search for usefulness between material concepts learned with real-world life situations.

One of the learning models that can be proposed is GSECE learning model has 5 important stages. Guiding first stage is the teacher gives instructions and directs students to determine the material or topics in accordance with the material to be studied. It aims to enable students to gain a higher understanding. According to Ulya states that with teachers give guidance to students in the learning process, it can bring students to a higher understanding [4]. This is in line with Vygotsky opinion which says that an actual child's developmental level with a higher level of potential development can be achieved by a child if received counsel or assistance from someone more mature or more competent [5]. Another opinion was also delivered by Nwagbo which states with the teacher provides guidance in the form of illustrations for students until students are able to generalize and conclude will make students able to apply the learning materials widely [6].

The second stage, Searching is the teacher gives the task of looking for information relating to the material or topics that can be obtained from reading and or images and video. It aims to provide opportunities for students to explore ideas independently and simultaneously optimize the potential of students to be able to master physics concepts well. According to Bruner learning activities will work well and creatively if the students find their own conclusions about the topics studied so that the concept can be understood more deeply and more lasting in the memory of students [5],[7]-[12]. Further Bajongga says that learning that optimizes the potential in students will foster creativity and students will be able to find and develop their own facts and concepts and problem solving [13].

The third stage of experiencing the teacher provides an opportunity for students to find the phenomenon or information related to the topic of everyday phenomena experienced by students. Learning that connects or links material or learning topics with the knowledge they have will make learning more meaningful [5], [14],[15]. This is supported by the opinion of Khaerul which states that learning that exposes students to problems in everyday life can be more meaningful and meaningful for students [16].

The fourth stage of communicating is the teacher giving the opportunity to students to communicate to peers about the material or topic of the search results and the results of the study based on the experience of students in everyday life. It aims to train students to communicate as well as to see the extent to which students master the material in learning activities. According to Piaget the process of exchange of ideas through communication and interaction with peers and adults plays an important role in the intellectual development of children and the formation of knowledge in children [5]. In addition, the communication will show the ability of students in understanding the material and with communication will also occur interaction and discussion with the group that makes students active in learning [17].

The fifth stage evaluating the teacher evaluates the student's learning outcomes after following the learning. It aims to obtain information and data that can be used as a basis to determine the level of progress, development, and achievement of student learning, and the effectiveness of teacher teaching. To obtain information and data of an accurate learning activities about the level of achievement of learning objectives by students it is necessary to evaluate learning activities that can be a test [18].

In relation to the issues discussed and proposed solutions on the advantages of the learning model, an experimental study was conducted to determine the effectiveness of the learning outcomes of the control class using conventional learning and experimental class using the GSECE learning model. In addition, to see student responses and activities of control classes using conventional learning and experimental classes using the GSECE learning model. 


\section{Methodology:-}

This study is a quasi experiment with the consideration that not all variables can be strictly controlled. The research design used was pre - post test control group design. The design of this study can be seen in table 1 as follows:

\begin{tabular}{|c|c|c|c|}
\hline Group & Pretest & Treatment & Post test \\
\hline $\mathrm{A}(\mathrm{n}=35)$ & $\mathrm{O}_{1}$ & $\mathrm{X}$ & $\mathrm{O}_{2}$ \\
\hline $\mathrm{B}(\mathrm{n}=35)$ & $\mathrm{O}_{1}$ & - & $\mathrm{O}_{2}$ \\
\hline
\end{tabular}

Table 1:- Pretest and post test control group design

The population in this study were the students of class X TKJ in SMK Negeri 7 Jember in the academic year 2017/2018. Before determining the control class and experimental class, Leven's test was tested from the daily physics value data on the previous material. This is to see the homogeneity of all sample candidates. After the test Leven's test obtained sample class X TKJ 1 with the number of students 35 people as a control group and class X TKJ 2 with the number of students 35 people as an experimental group. The dependent variable in this study consists of learning outcomes, student responses and student learning activities. The independent variables consist of the GSECE learning model for the experimental group and the conventional learning model for the control group. Data collected in this study include learning outcomes measured by using tests, student responses measured by questionnaire and student activity measured by observation sheet.

Data were analyzed with independent sample t-test to determine the main difference of independent variable (learning model) to dependent variable (learning result). Descriptive analysis techniques used to describe student responses and student learning activities.

\section{Result:-}

The result of the research described is the learning achievement achieved by the students between the groups after following the learning model of GSECE (experimental group) and conventional model (control group). The results are presented in Table 2 .

\begin{tabular}{|l|c|c|c|c|c|c|}
\hline \multicolumn{1}{|c|}{ Group } & $\mathrm{n}$ & Mean & SD & $\mathrm{t}$ & df & Sig (2-tiled) \\
\hline Eksperimen & 35 & 78,29 & 6,34 & 4,75 & 68 & 0,00 \\
\hline Control & 35 & 71,14 & 6,23 & & & \\
\hline
\end{tabular}

Table 2:- Results of post test analysis with independent sample t-test

Table 2 shows that the mean post-test scores of the experimental group students were 78.29 ( $\mathrm{SD}=6.34$ ), and for the control group students were $71.14(\mathrm{SD}=6.23)$. It shows that the learning outcomes of students who follow the learning with the GSECE model is higher than students who follow the learning with conventional teaching methods. Based on Table 2, $t$ obtained $=4.75$ indicates that the value of $t$ count $>t$ table (4.75>1.99) and $\mathrm{P}$ value $(0,000<0.05)$ then $\mathrm{Ho}$ is rejected, meaning that there is a difference between the average value experimental group exams with an average of control group exam.

Student responses in the experimental group using the GSECE learning model with the control group using the conventional learning model are presented in Table 3.

\begin{tabular}{|l|c|c|}
\hline \multirow{2}{*}{} & \multicolumn{2}{|c|}{ Student Reponse } \\
\cline { 2 - 3 } & GSECE learning model & Conventional learning model \\
\hline Percentage average & 78,46 & 60,45 \\
\hline Category & good & good enought \\
\hline
\end{tabular}

Table 3:- Description of student response value

Based on Table 3 can be described that the response of students in the experimental group learning using GSECE learning model obtained the average value of 78.46 percentage including good category while the student response in the control group using the conventional learning model obtained the average value of percentage of 60,45 including the category is quite good. From the above data, it can be described that the student response using GSECE learning model is better than conventional learning model. 
Student activity in the experimental group using the GSECE learning model with the control group using the conventional learning model is presented in Table 4.

\begin{tabular}{|l|l|c|c|}
\hline No & \multicolumn{1}{|c|}{ Student learning activities indicators } & \multicolumn{2}{c|}{ Student learning activities } \\
\cline { 3 - 4 } & \multicolumn{1}{|c|}{$\begin{array}{c}\text { GSECE learning } \\
\text { model }\end{array}$} & $\begin{array}{c}\text { Conventional } \\
\text { learning model }\end{array}$ \\
\hline 1 & $\begin{array}{l}\text { Observe and accept the explanations of teachers and friends } \\
\text { during the learning process }\end{array}$ & 80,00 & 68,8 \\
\hline 2 & $\begin{array}{l}\text { Respond by asking and providing answers during the learning } \\
\text { process }\end{array}$ & 76,43 & 58,3 \\
\hline 3 & $\begin{array}{l}\text { Appreciate and listen to the opinions of teachers and friends } \\
\text { during the learning process }\end{array}$ & 70,71 & 52,08 \\
\hline 4 & $\begin{array}{l}\text { Organize, process information, and solve problems to make } \\
\text { decisions }\end{array}$ & 57,86 & 62,14 \\
\hline 5 & $\begin{array}{l}\text { The overall assessment which includes asking or answering } \\
\text { questions well, doing the cooperation in one group well, and } \\
\text { having a sense of responsibility for the opinions that have been } \\
\text { submitted }\end{array}$ & 64,29 & \\
\hline & Percentage average & 69,86 & 62,92 \\
\hline & Category & active & active \\
\hline
\end{tabular}

Table 4: Description of student learning activity values

Based on Table 4 it can be explained that the student activity in the experimental group using the GSECE learning model obtained the average value of the percentage of 69.86 including the active category. Student activity is control group which use conventional learning model obtained by average value percentage equal to 62,92 including active category. From the above data, it can be described that in the experimental group using the GSECE learning model the students are better than the control group using the conventional learning model.

\section{Discussion:-}

This study aims to determine the effectiveness of GSECE learning model with learning outcomes, student responses and student learning activities. From the results of this study indicate that there is a significant difference in the average of student learning outcomes of students who learn to use the GSECE model is 78.29 with the group of students who learn to use conventional learning model that is 71.14 .

The results of the overall hypothesis testing previously described show that the GSECE learning model through five important stages of learning has proven superior effectiveness toward learning outcomes, student responses and student activities compared with conventional learning models.

The main factor that makes the GSECE learning model more superior lies in its syntax which emphasizes students using all their potential to seek, and find their own concepts and then connect with experience in everyday life. The learning model with students looking for, finding and connecting experiences in daily life can be more meaningful learning [19] and can sharpen intelligence and enable students to respond effectively to learning materials [20]. Another relevant study conducted by Mulyasa states that the reasoning that optimizes the potential of students seeking, finding and experiencing directly proven to increase student motivation in learning so that students become more active in teaching and learning activities [21].

\section{Conclusion:-}

Based on the research results can be concluded several things as follows. First, the results of physics learning between the groups of students who were given learning with the GSECE model better than the group of students who were given a conventional learning model. Both student responses in the group of students who were given learning with the GSECE model were better than the group of students who were given the lessons with the conventional model. The three activities of the students in the group of students who were given learning with the GSECE model were better than the group of students who were given the conventional learning model. 


\section{References:-}

1. Basaga H, Geban O, Tekkaya C, "The Effect of the Inquiry Teaching Method on Biochemistry and Science Process Skills Achievements", Biochem. Educ. 22:29-32, 1994. (journal style)

2. Akinbobola, A.O. \& Ado, I.B, "Hands-on and minds-on strategies for teaching of force: guided discovery approach (pp. 65-72). In.: Udo, E., Uyoata, U, Inyang, N.E.O., Yero, H. \& G.Bellp, G. (Eds.). Hands-on and minds-on strategies in the teaching of force", Uyo: Afahaide \& Bros Printing and Publishing Co, 2007.

3. Texas Collaborative for Teaching Excellence, "What We Know about the Learning Process", (http://www.texascollaborative.org What We know about the learnig.htm) accessed January 24, 2011.

4. Ulya Izzatul, "Application of Learning Guided Discovery Learning Model Based on Lesson Study in Mathematics Class VIII Odd Semester at UPTD SMP Negeri 1 Prambon School year 2013/2014", National Conference on Research on Mathematics and Learning (KNPMP I) 67, Muhammadiyah university, Surakarta, 2016.

5. Dahar, R. W, "Theories of Learn and Learning”, Jakarta: Erlangga, 2011.

6. Nwagbo, C, "Effects of Guided-Discovery and Expository Teaching Methods on the Attitudes Towards Biology of Students of with Different Levels of Scientific Literacy”, J. Science Teachers Association of Nigeria (STAN), 36, 43-51, 1999.

7. Bilgin, I, “ The Effect of Hands-On Activities Incorporating a Cooperative Learning Approach on Eight Grade Student Science Process Skills and Attitudes Toward Science”, J. Baltic Sci. Educ. 1 (9): 27-37. 2006.

8. Alliance for Childhood, "Fiil's Gold: A Critical Look at Computers in Childhood. Retrieved from http://www.allianceforchildhood.net/projects/computers/computers_reports.htm. 2000.

9. Bredderman. T, "Effect of Activity-Based Elementary Science on Student Outcomes: A Quantitative Synthesis", Review of Educational Research, 53, 499-518. 1983.

10. McDaniel, M. A. \& Schlager, M. S, “ Discovery Learning and Transfer of Problem Solving Skills”, Cognition and Instruction, 7, 129-159, 1990.

11. Schauble, L, "The Development of Scientifict Reasoning in Knowledge-Rich Context", Development Psychology, 32, 102-119, 1996.

12. Stohr-Hunt, P, M, “An Analysis of Frequency of Hands-on Experience and Science achievement”, Journal of Research in Science Teaching, 33, 101-109, 1996.

13. Bajongga, S, "Relationship Between Mastery of Physical Concept and Creativity with Problem Solving Ability in Basic Material of Static Electricity", Journal of Research Field Research. ISSN: 0852-0151, Vol. 20 (1): 65$75,2014$.

14. Mayer, R.E, "Learning and instruction", New Jersey: Pearson Education Inc, 2003.

15. Bromley, K., Irwin-Devitis, A. \& Modlo, M, “Graphic organizers”, New York: Scholastic Professional Books, 1995.

16. Khaerul, et al, "Influence of problem-based model (PBM) using E-material-based teaching materials on understanding concept of physics on the students of class X SMA Negeri 1 Bimomaru", Journal Physics Education Tadulako. ISSN: 2338-3240, Vol. 1 (3): 23-26, 2013.

17. Hamdayana, J, "Models and Methods of Creative Learning and Character", Bogor: Ghalia Indonesia, 2014.

18. Trianto, "Integrated Learning Model: Concepts, Strategies and Implementation in Education Unit Level Curriculum (KTSP)", Jakarta: PT. Earth Script, 2010.

19. Afolabi, F\& Akinbobola, A.O, "Constructivist problem based learning technique and the academic achievement of physics student with low ability level in Nigerian secondary schools", Eurasian J. Physics \& Chemistry Education, 1, 45-51, 2009.

20. Sapto et al, "Learning Models in Environmental Education IT-Based at Vocational High School", Ansinet: Journal if Applied Science, ISSN 1812-5654, 2015.

21. Mulyasa, "School Based Management", Bandung: Remaja Rosdakarya, 2006. 